Economia e Sociedade, Campinas, Unicamp. IE. http://dx.doi.org/10.1590/1982-3533.2019v28n2art04

\title{
Ecological macroeconomics: a methodological review *
}

\author{
Beatriz Macchione Saes ** \\ Ademar Ribeiro Romeiro ${ }^{* * * *}$
}

\begin{abstract}
The paper aims to analyse and provide an overview of the emerging ecological macroeconomic approach from a methodological point of view. As with ecological economics, this emerging approach is being constituted by a methodologically plural set of studies. We identify and classify three main macroeconomic strands developed from ecological economic concerns. Firstly, we present the conventional macroeconomic IS-LM model adapted to a sustainable scale of production. Secondly, we discuss a fundamentalist post-Keynesian view on ecological economics that criticises the use of models more heavily. Finally, we describe the attempts to build ecological macroeconomic models based on the post-Keynesian approach. For each model, theories, methods, and assumptions are discussed and evaluated in light of ecological economic foundations. We conclude by reinforcing the role of methodological criticism in the consolidation of relevant ecological macroeconomics.
\end{abstract}

Keywords: Ecological macroeconomics; Methodological pluralism; Post-Keynesian macroeconomics.

\section{Resumo}

Macroeconomia ecológica: uma revisão metodológica

O objetivo do artigo é apresentar e analisar a abordagem macroeconômica ecológica do ponto de vista metodológico. Como a economia ecológica, esta abordagem emergente está sendo constituída por um conjunto metodologicamente plural de estudos. Identificamos e classificamos três principais vertentes macroeconômicas desenvolvidas a partir de problemáticas econômico-ecológicas. Em primeiro lugar, apresentamos o modelo macroeconômico convencional IS-LM adaptado a uma escala de produção sustentável. Em segundo lugar, discutimos uma visão pós-keynesiana fundamentalista para a economia ecológica mais crítica ao uso dos modelos. Finalmente, descrevemos as tentativas de construir modelos macroeconômicos ecológicos baseados na abordagem pós-keynesiana. Para cada uma delas, teorias, métodos e pressupotos são discutidos e criticados à luz dos fundamentos econômicos ecológicos. Concluímos reforçando o papel da crítica metodológica para a consolidação de uma macroeconomia ecológica relevante.

Palavras-chave: Macroeconomia ecológica; Pluralismo metodológico; Macroeconomia pós-Keynesiana. JEL B41, E12, Q57.

\footnotetext{
* Article received on April 7, 2017 and approved on March 2, 2018. Research for this paper benefited from a Capes scholarship (process n. BEX 6505/15-5) provided to the first author. The authors wish to thank Joan Martínez-Alier, Lorenzo Pellegrini, Gustavo de Oliveira Aggio and Frederico Demaria for helpful comments on previous versions of this paper. The usual disclaimers apply.

${ }^{* *}$ Postdoctoral Researcher (PNPD-Capes) at the Federal Fluminense University (UFF), Niterói, RJ, Brazil. Email: beatrizmsaes@gmail.com.

${ }^{* * *}$ Professor at the University of Campinas (Unicamp), Campinas, SP, Brazil. E-mail: arromeiro@gmail.com.
} 


\section{Introduction}

There is a growing awareness that we are experiencing a triple environmental, social and economic crisis (e.g. Schneider et al., 2010; Røpke, 2016). However, equating sustainable development paths with social progress or a reduction in inequalities does not appear to be straightforward. While most economists still believe that the answer to these challenges relies on more economic growth, other researchers have deliberated how to achieve or transit to a sustainable and thriving economy capable of satisfying human needs without depending on continuous unsustainable economic growth. Particularly since the financial crisis of 2008, there has been "a revival of the growth debate" (van den Bergh, 2010, p. 543), chiefly among ecological economists as well as participants of the degrowth movement, as the crisis was also considered an opportunity for social transformation (Schneider et al., 2010).

In the field of ecological economics, Herman Daly (1991) stated the lack of an ecological macroeconomic approach at the beginning of the 1990s. However, despite the field's paradigmatic critique of economic growth, there were few and isolated advances in the area until recently. In the post-2008 context, faced with stiff disbelief in mainstream economics, many ecological economists also saw in the crisis an opportunity to promote alternative macroeconomics. In the following years, the enormous repercussion given to the subject, even among public opinion, was largely a consequence of two publications written by Peter Victor and Tim Jackson. Victor (2008) explored, through computer simulations, the possibilities to manage the Canadian economy without growth. The study was received with optimism among ecological economists because it showed that a non-growing economy in Canada would not necessarily produce a social catastrophe since governments could manage a process of gradual growth decline. Jackson (2009) spread the term "prosperity without growth" and highlighted the need for ecological macroeconomics, inspiring many subsequent works characterized by significant methodological pluralism.

Thenceforth, the term "ecological macroeconomics" began to be used recurrently. Harris (2008, p. 1) considers that ecological macroeconomics must make it possible to achieve a low-carbon path that "requires population stabilization, limited consumption, and major investments in environmental protection and social priorities". Jackson (2009, p. 141) claims "that new ecological macroeconomics is not only essential but possible" and that one starting point is "to relax the presumption of perpetual consumption growth as the only possible basis for stability." Jackson and Victor (2011, p. 108) emphasize "the challenge of building a genuinely ecological macroeconomics, in which economic stability can be achieved without relentless consumption growth". More recently, the use of the term was reinforced by Rezai, Taylor and Mechler (2013), Urhammer and Røpke (2013), Jackson et al. (2014), Røpke (2013; 2016) and Fontana and Sawyer (2016).

Only recently, Rezai and Stagl (2016) presented an ecological macroeconomic review in the editorial for a special edition on the subject (Ecological Economics, 2016). They provide a good overview of works related to ecological macroeconomics in a broader sense, even 
including the development of new welfare indicators ${ }^{1}$. Hardt and O'Neill (2017) provided a narrower review in their analysis of ecological macroeconomic models and their capability to assess policies proposed for a "post-growth" economy ${ }^{2}$. In our paper, we take a different perspective by focusing on methodological choices behind these models instead of proposed policies or economic subjects. That is, we analyse ecological macroeconomic contributions in light of the methodological positions implied in each set of models.

Therefore, we seek the support of economists and ecological economists in methodological studies to better understand the methodological choices behind ecological macroeconomics. The central concept that guides our methodological discussion is pluralism. In general, methodological pluralism has been accepted by ecological economists since the field's beginning (see Norgaard, 1989; Costanza, 1991). The basic idea behind this claim is that pluralism is crucial to addressing the complex relations between economies and ecosystems. However, many authors criticize this perspective arguing that accepting any method could lead to an irrelevant ecological economic approach. If methodological pluralism is to be accepted in ecological economics, it should not eliminate the criteria to select the most appropriate methods in light of ecological economic foundations (Spash, 2012; Söderbaum, 2011).

The paper is divided into five sections. In section 1, we briefly describe heterodox and orthodox macroeconomics and their methodological positions in light of ecological economic foundations. Section 2 presents a conventional macroeconomic model adapted to an economically sustainable scale. Section 3 follows with a discussion of post-Keynesian and ecological economic perspectives on economic and ecological uncertainty and the limits of models to analyse them. Section 4 describes the attempts to build ecological macro dynamics based on the post-Keynesian approach. Finally, we present some concluding remarks emphasizing the role of methodological criticism.

(1) Indeed, the development of welfare indicators is significant for ecological macroeconomics since more appropriate indicators of welfare can be used as goals not only for economic policies but also for macroeconomic models. That is, ecological macroeconomic models may use different welfare indicators so as to take into consideration various aspects of well-being. For instance, the Genuine Progress Indicator (GPI) takes into account environmental and social factors which are not measured by GDP. For an estimation of GPI for Brazil see Andrade and Garcia (2015).

(2) "Post-growth" is employed to summarize all the literature aiming "to develop a vision for a prosperous economy that does not rely on economic growth" (Hardt and O’Neill, 2017, p. 198). That includes "steady-state economics", "the new economics of prosperity" and "degrowth". Indeed, as many ecological macroeconomics models are concerned with policies that can make possible paths visualized by such approaches, there are many common points regarding suggestions and challenges among these strands and ecological macroeconomics. However, like Hardt and O'Neill (2017), henceforward, we will not distinguish between such approaches to focus exclusively on the discussion about ecological macroeconomics models. Also, for the same reason, we left aside the efforts to develop what could be defined as Marxist ecological macroeconomics. Authors that could be included in this perspective are James O’Connor, Elmar Altvater, John Bellamy Foster and David Harvey. 


\section{Methodological considerations: pluralism in ecological macroeconomics?}

Most ecological economists are in favour of methodological pluralism, albeit with different views on its implications. In 1989, Richard Norgaard began this discussion in the first Ecological Economics' edition. As the field was beginning to consolidate, Norgaard (1989, p. 51) argued in favour of a provisional pluralism, which could stimulate the debate on the adequacy of different methods, since it was "clearly too early to limit the methodologies used in ecological economics now [1989] even if a narrower set might be agreed upon later". On the other hand, the author highlighted the importance of permanent pluralism to deal with the complexity of ecological economics: "the multiple insights of multiple methods constantly remind us of the complexity of a social and ecological system and the difficulties of taking action" (Norgaard, 1989, p. 52).

Ecological economists accepted methodological pluralism as a core idea in the field. However, this idea was incorporated from two divergent perspectives. Influential ecological economists, like Costanza, Perrings and Cleveland, promoted the idea of uncritical or unstructured pluralism (Spash, 2012). This position, based on the principle "anything goes"3, strengthened the presence and influence of neoclassical economics in the field. Possibly, this contributed to a rapid rise of publications and participation in conferences and the use of procedures shared by neoclassical economists and natural scientists, especially mathematical models, and abstract language (Røpke, 2005). Nevertheless, uncritical pluralism contradicts several researchers who defend a particular pre-analytical view of ecological economics. Spash (2012, p. 46) asserts that "Ecological economics can either develop a more rigorous approach and establish a theoretical structure or become increasingly eclectic, unfocused and irrelevant." According to Anderson and M'Gonigle (2012, p. 37), "this pluralism led to an increasing neoclassical presence that has diminished the power of the field's original break with mainstream orthodoxy." Similarly, Gowdy and Erickson (2005, p. 19) state that ecological economists are at a crossroads: "We can lead the charge to merge the social and biophysical critiques, or we can fall prey to a caricature of ecological economics as Walrasian wine in a new bottle."

The contradictions pointed out by these authors should not necessarily result in methodological pluralism denial. On the contrary, many ecological economists defend a critical or structured methodological pluralism (see Spash, 2012; Söderbaum, 2011). Most of their arguments are based on methodological studies developed by economists such as Bruce Caldwell, Tony Lawson and Sheila Dow. Caldwell (1990) coined the term "critical pluralism", giving that criticism plays a crucial role in the choice of methods and, consequently, knowledge advancement. If we accept that there is no consensus about the characteristics of a universal scientific model, it is essential to reject dogmatic models and to develop alternative methods (Caldwell, 1994). However, to prevent pluralism from leading to anarchism or scepticism,

(3) A principle defended by Paul Feyerabend (1975), which featured an anarchist view of science, rejecting the existence of universal methodological rules. 
Caldwell (1989) advocates a critical process of different research programs, in which some methodological views appear to be better than others.

Dow (1997) promotes an ontological and epistemological discussion that leads to "structured pluralism" - also called "Babylonian pluralism of method". Accordingly, this methodological position depends on the ontological and epistemological positions of each research program. Neoclassical economics, for instance, is based on closed system ontology, which gives that reality is composed of universal regularities. Also, it assumes that facts can be understood uniquely and objectively (epistemological monism). Methodological monism in mainstream economics can be understood as a consequence of the belief that we can fully know systems regularities. On the other hand, if we considered reality as an open system, in which the sample of variables and their interrelation structures are not predetermined, we recognize the limitations of human understanding and admit the importance of methodological pluralism.

Ecological economic foundations show significant similarities with open system ontology. From the field's biophysical view, based on thermodynamic laws, the reality is defined as complex, implying vague knowledge about economic and ecological systems. Spash (2012) emphasizes other factors that distinguish ecological economics ontology from the neoclassical approach: value and facts are inseparable; the world's state is characterized by social indeterminacy, emergent proprieties, and a historical dynamic process; and society cannot be reduced to the individual as it cannot be the result of individual's aggregation. These factors also characterize open system ontology and are largely shared by heterodox economists.

Mainstream macroeconomics - characterized by presenting some general equilibrium approach as a common factor - is based on closed system ontology and methodological monism. Now, the neoclassical Keynesian synthesis is in the general equilibrium tradition; i.e., concludes a closed system of simultaneous equations ${ }^{5}$. However, it did not derive exclusively from an axiomatic theory or methodological individualism, like mainstream tradition, relying somehow on empirical analysis. Only after the 1970s did mainstream macroeconomics advance towards deriving "macroeconomic relationships from the same axioms of rational behaviour as neo-classical microeconomics" (Dow, 1985, p. 66). In the early 1970s, new Keynesian economics, headed by Lucas and Sargent (1978), implemented a radically reductionist research program that wholly denied any autonomy of macroeconomics concerning general equilibrium microeconomics (Vercelli, 1991).

(4) Feynman (1965) employed the concept of Babylonian thought concerning Babylonian mathematics in contrast to the axiomatic approach of Greek mathematics. Deductive axiomatic mathematics was inefficient for practical purposes given that it made many assumptions and required long chains of reasoning vulnerable to errors. Babylonian mathematics, in turn, used different and short chains of reasoning starting from different points and employing different methods (Dow, 2005).

(5) In contrast to Keynes (1936) - who demonstrated, based on money features, that the economic system was characterized by instability, uncertainty, and disequilibrium -, economists working within the synthesis, like Hicks (1937, 1939), Modigliani (1944) and Patinkin (1948, 1956), claimed that economic disequilibrium (i.e., unemployment) would occur exclusively due to temporary imperfections of market mechanisms, such as price or wage rigidities. 
Neoclassical Microfoundation as a methodological strategy of mainstream macroeconomics, which depends on strong assumptions such as agents' homogeneity and rational expectations, can be criticized for providing an unrealistic portrayal of reality ${ }^{6}$. In the Keynesian tradition, the agents' heterogeneity is a fundamental component of open system reality which imply uncertainty in investment decisions and the possibility of disequilibrium due to insufficient demand. A theory committed to explaining the real world should attempt to understand it, even if providing complete explanations is not feasible due to the complex nature of reality (Mearman, 2009). Similarly, Lawson (2003) argues that prediction is difficult or even impossible in social sciences because these sciences address open systems. Also, he assumes a radical position against mathematical formalism. Formal models could only be applied in contexts where local closure exists; consequently, only in rare circumstances (Hodgson, 2009).

Despite the lack of consensus among ecological economists regarding a methodological position, since the 1980s, when the discussion around methodological issues was taking place, there was a significant increase in mathematical formalism in Ecological Economics (Silva and Teixeira, 2011). Leading ecological economists like Costanza (1991) have supported this increase and defended formalism in different ways - from the use of conventional economic and ecological models to computer simulations of complex dynamics. In another direction, Spash (2012, p. 45) asserted that "the continued support for mathematical formalism and quantification as providing the sole means to scientific rigor and validity is damaging to an alternative vision for ecological economics".

As a rule, ecological economists agree that, in the last decades of the $\mathrm{XX}$ century, mainstream mathematical formalism revealed limitations to address environmental issues. Neoclassical environmental economics applied to environmental policy was unable to resolve problems such as global climate change and worldwide loss of biodiversity. This is largely due to its central proposition in terms of "solving" environmental problems - that is, to internalize externalities into the price system. Therefore, ecological economists criticize, as well as the unrealistic assumptions of neoclassical economics, its prediction power, as "some of the fundamental assumptions of neoclassical utility theory (...) are not only unrealistic but also have had unforeseen and unfortunate consequences for environmental and social policy" (Mayumi, 2001, p. 20). Moreover, this perception was amplified among ecological economists after 2008 since very few mainstream economists foresaw the global financial crisis (Jackson, 2009; Kallis et al., 2009).

Uncertainty is a crucial concept for ecological economists and post-Keynesians to understand, respectively, ecological and financial crises. For instance, to analyse complex issues, such as climate change, in which we face uncertainty, "we need several different strands of reasoning and evidence to understand its causes" (Mearman, 2009, p. 39). In this sense, Holt,

(6) Unrealistic theory in economics (i.e., neoclassical economics) was methodologically defended by Friedman's (1953) instrumentalism. Accordingly, it does not matter if the theory is descriptively unrealistic, or if its assumptions are not valid, as long as it provides adequate predictions. 
Pressman and Spash (2009) believe that the dialogue between both perspectives, that share the view that economic and ecological processes are uncertain, complex and irreversible, brings new elements to understanding economic and ecological sustainability. Regarding macroeconomics, Spash and Schandl (2009) assert that since there is no consolidated macroeconomic theory related to ecological economics, considered a new approach, it could benefit from the heterodox view of post-Keynesian economists. Accordingly, for ecological economics "a more heterodox macroeconomic approach sharing basic methodological concerns would, therefore, be a significant step forward" (Spash and Schandl, 2009, p. 49).

However, we know that, despite sharing common essential assumptions about the role of aggregate demand and the dynamical time, different post-Keynesian strands offer distinct approaches to understanding our very uncertain economic world - the same challenge posed to ecological economics. That is, why some ecological economists address the fundamentalist post-Keynesian strand, while others develop their analyses mainly based on the Kaleckian strand. ${ }^{7}$ The first is more concerned with issues like fundamental uncertainty ${ }^{8}$ and monetized production economy. Also, they tend to be more dedicated to methodological studies and opposed to mathematical formalism. The second emphasizes Kaleckian's successful contributions to building formal macroeconomic models, which require additional restrictive axioms generally not accepted by fundamentalist post-Keynesians. Despite the additional axioms, they developed models capable of handling the complexity and the uncertainty of economic dynamics. Their dynamic macroeconomic models often emphasize the nonlinear relations in the economy that can lead to endogenously complex fluctuations (Rosser Jr., 2009).

Nevertheless, like ecological economics and heterodoxy in general, post-Keynesian strands also criticise neoclassical economics. In other words, they share a consensual opposition to mainstream abstractions and simplifications of economic reality that lead to its misunderstanding and mistakes in economic policy formulation. The orthodox methodological monism, which advocates just one way to build knowledge, only makes sense if the real world is a closed system - i.e., if individuals are atomistic and invariants, if endogenous variables do not affect closure and if the economy is an isolated system. By contrast, ecological economics and post-Keynesian economics focus on understanding and explaining the complex social reality. Indeed, ecological macroeconomics seems more likely to develop new ideas as a result of cross-fertilization with heterodox macroeconomics. According to Lawson (2003, p. 166):

(7) Another post-Keynesian strand, according to the typical division of Hamoud and Harcourt (1988), is formed by the Sraffians. However, several post-Keynesian methodologists claim that they should not be included within post-Keynesianism because they are far from the critical realism perspective (Lavoie, 2014). Specifically, they abstract from uncertainty in their longrun analysis. For us, this demarcation is not essential as there are no clearly Sraffian contributions to ecological macroeconomics.

(8) Fundamental uncertainty "is characterized by the possibility of creativity and non-predetermined structural change. Within the bounds imposed by natural laws, the list of possible events is not predetermined or knowable ex-ante, regardless of what people do, as the future is yet to be created" (Dequech, 2011, p. 623). From now on, we will consider uncertainty as fundamental uncertainty. 
(...) the particular ontological commitments which drive the different heterodox traditions are reasonably similar to each other. Or at least, this is so for those strands of these traditions that do embrace the possibility of and concern themselves with, pursuing constructive programmes.

Finally, by assuming that social and economic reality contains a large variety of unique situations and uncertainties, post-Keynesianism and ecological economics are possibly consistent with some methodological pluralism. This does not exclude, however, the need to choose more appropriate practices according to specific contexts and the evaluation by researchers of different heterodox traditions. In ecological macroeconomics, the evaluation must take into account ecological economic foundations. Thus, methodological pluralism in ecological macroeconomics should not only embrace criticism of some orthodox and heterodox basic assumptions about unlimited economic growth but also result from an open system perspective, requiring methods that are capable of dealing with uncertainty, instability, and complexity.

\section{Biophysical limits in "mainstream" ecological macroeconomics}

Hardt and O'Neill (2017, p. 201) decided a priori "to exclude all models that assume optimization processes" from their survey, based on an undeveloped argument that it is simply "consistent with the trend of rejecting orthodox approaches in the ecological macroeconomics literature." Even if our methodological discussion could suggest the same path, we decided to consider these models in our discussion since some of them have repeatedly been published in the area's leading journal, Ecological Economics, and have even been mentioned by one of the founders and most important researcher in ecological economics, Herman Daly. The discussion around the advances and limitations of these models may also help to provide the basis for setting limits and defining this emerging research area. It is also important to highlight that the models presented in this section are based on neoclassical synthesis macroeconomics and have, like other ecological macroeconomics models, a Keynesian inspiration in the sense that the product may remain below the productive capacity of the economy.

Daly and Farley (2011, p. 347-350), for instance, firstly suggest imposing an external constraint on an IS-LM model representing the biophysical limits of ecosystems. The vertical line EC (ecological capacity) represents the maximum sustainable throughput (Fig.1). The purpose of this vertical line in a conventional model was undoubtedly mainly didactical. Economic production (Y) beyond EC means that economic equilibrium has overshot the biophysical equilibrium. The correspondence between economic equilibrium (Y) and biophysical equilibrium (EC) represents a "big coincidence" or "purposeful coordination and planning." Therefore, the IS-LM-EC model indicates the relevance of policies to impose limits on throughput, although increased efficiency of resource use could increase EC. 
Figure 1

IS-LM-EC diagram

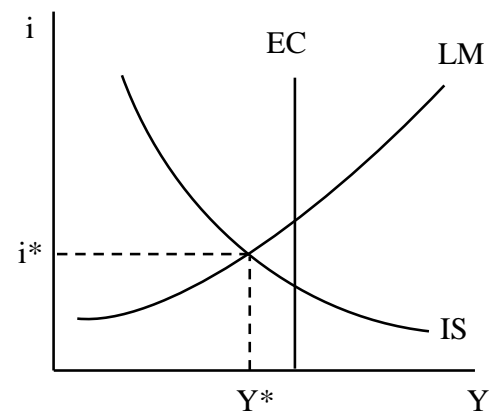

Source: Daly and Farley (2011 [2004], p. 349).

Heyes (2000) made a more in-depth effort to develop an ecological macroeconomic model for conventional macroeconomic textbooks. Also, he aimed to answer Daly's (1991, p. 33) question on how to address the environment in textbooks. Heyes's model presents the introduction of the EE curve (environmental equilibrium) in the IS-LM model (Fig.2). It allows the environment to be analysed as a precondition for growth and not just an externality. The EE curve represented the steady-state so that at any point in the curve the rate at which the economy is using environmental services is equal to the environment's ability to supply them - i.e., the environmental degradation rate is zero. As environmental services used in production depend on the technology employed, different combinations of interest rate $(\mathrm{R})$ and production levels (Y) can produce environmental equilibrium. Namely, EE is an isoquant. The movement along the isoquant is explained by the fact that, given the institutional framework (or environmental regulation), an increase in the capital cost (R) will result in the adoption of a less environmentally friendly technology and vice versa. In turn, variations in the institutional framework cause the isoquant displacement: lax institutional frameworks shift EE to the left and vice versa (Heyes, 2000).

Figure 2

IS-LM-EE diagram

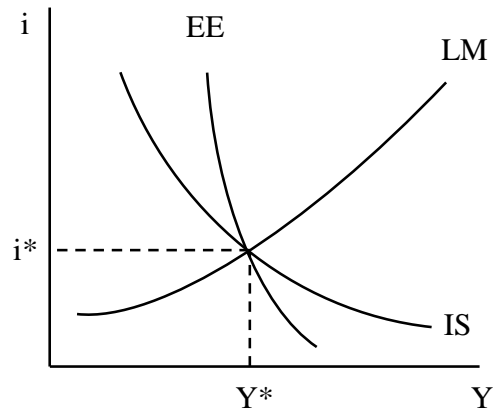

Source: Heyes (2000, p. 4). 
Via the IS-LM-EE model, monetary and fiscal policy can be analysed. For instance, an expansionist fiscal policy would lead to an economic output incompatible with environmental equilibrium. To remain within EE, this policy must be accompanied by a restrictive monetary policy - that would lead to a lower output. However, this exogenous adjustment again depends on the condition that the policymaker has perfect knowledge about the ecological equilibrium and the precise amount of fiscal and monetary policy to achieve it. As in the IS-LM-EC model, remaining in environmental equilibrium requires excellent coordination and planning, contradicting IS-LM foundations. In other words, both models cannot be based on automatic economic adjustments by market mechanisms.

To improve these models, Lawn (2003) and Sim (2006) attempted to make the IS-LMEE framework more faithful to IS-LM natural adjustment. Lawn (2003) built an IS-LM-EE version with a technological parameter - similar to Heyes' institutional parameter - and analysed the effects of cap-and-trade policies. Technological innovations move EE to the right, extending the limits under which the production level may remain in environmentally sustainable conditions. However, if environmental impacts of economic activity are higher than the self-regeneration capacity of nature, the increasing environmental degradation ultimately reduces nature's carrying capacity, shifting the EE curve to the left. Also, considering the use of cap-and-trade policy, fiscal expansion raises the cost of resources, encouraging less resource-intensive technologies and shifting the EE curve to the right. The level of the output compared to the original depends on the shape of the curve, the level of technological progress achieved and the effect of cap-and-trade on prices. In any case, appropriate institutional arrangements are necessary since natural market forces cannot ensure macroeconomic adjustment towards EE. Therefore, policymakers must also know the environmental constraints to emit the appropriate number of cap-and-trade permits.

By contrast, Sim's version operates like standard IS-LM: one solution is produced through a system of simultaneous equations - macro-environmental equilibrium - that does not change unless the initial conditions are changed. The author declares that "it is plausible that a natural adjustment mechanism exists in the IS-LM-EE framework" because environmental damage affects consumption and investment levels - components of the IS equation (Sim, 2006, p. 402) - negatively. For instance, higher pollution levels may affect workers' health, probably reducing their productivity. Therefore, fiscal expansion in a country where the output is higher than the environmentally sustainable level would not impact the long-run equilibrium. In other words, the fiscal expansion would lead to reduced environmental quality, generating social costs that reduce planned expenditure. In this case, higher environmental regulatory standards that shift EE to the right are essential to allow higher output levels in the long run.

Finally, Moraes and Serra (2011) expanded the IS-LM-EE model to take international trade into account which is frequently neglected by ecological macroeconomics. Since trade ultimately redistributes the environmental burdens around the world, the initiative of analyzing open economies is indispensable to understanding the sustainable paths of individual countries. 
Based on the well-known Mundell-Fleming model of open economies, they make the EE curve susceptible to exchange rate movements. Moreover, they emphasize contrasting environmental effects of trade on developing and developed countries. While developing countries export resource-intensive products, developed countries mainly export manufactures and also have more rigid regulations regarding environmental impacts. Therefore, an exchange devaluation leading to increased exports may have perverse environmental effects mainly in developing countries, shifting the EE curve to the left (the opposite direction to the displacement produced on the IS curve).

In all previous models, there is an implicit assumption that capital and natural resources are to some extent substitutes. Generally, this assumption reinforces technological optimism, including the neoclassical economic prediction that price mechanism is sufficient to offset any shortages of natural resources ${ }^{9}$. To develop a model with a strong sustainable point of view, Decker and Wohar (2012) work with the opposite assumption, namely that physical capital and environmental capital are complements in production. This assumption implies an upwardsloping EE curve: under environmental equilibrium, an increase in the interest rate is associated with a higher output. The new EE curve also implies different monetary and fiscal policy results ${ }^{10}$.

Despite the most recent improvement, IS-LM-EC and IS-LM-EE models are mainly concerned with one crucial ecological economic issue - that is, biophysical limits. They do not tackle the macroeconomic consequences of uncertainty, complexity, and irreversibility in ecological and economic processes. Daly and Farley (2011, p. 348) suggested their adaptation of the IS-LM model to ecological economics as a "good place to start". However, the absence of relevant ecological economic concerns is even more explicit in more developed models.

In the model that considers automatic adjustment, production remains within the environmentally sustainable level in the long-run due to the social costs of poor environmental standards (Sim, 2006). However, one would hardly expect these costs to be increasingly and linearly perceived by society to an extent that would prevent threatening the resilience of the ecosystem or crossing certain biophysical thresholds. Crossing certain biophysical thresholds could imply a shift between states with severe consequences on humanity, with the aggravating factor that the locations of these thresholds are very often unknown. As these are complex systems, and may react in a nonlinear way, it is hard to predict the moment and the results of crossing threshold levels (Rockström et al., 2009). Therefore, focusing only on biophysical

(9) Neoclassical economists state that natural resources are similar to other production factors so that other factors can substitute resources - i.e., capital (Solow, 1974; Stiglitz, 1979). Accordingly, the price mechanism would be sufficient to offset any shortage, since the price increase of a scarce resource reduces its consumption and leads to its replacement by other less scarce resources (see the special issue in Ecological Economics, 1997).

(10) For instance, a fiscal stimulus that leads to an output beyond EE must be accompanied by restrictive monetary policy. However, as the EE slope is now positive, the shift in LM is less dramatic than in Heyes (2000). Therefore, when inputs are complements in production, fiscal policy may be expansionary (Decker; Wohar, 2012). 
limits, while disregarding other ecological economic foundations, may imply overlooking critical environmental impacts of economic activity.

Furthermore, although the models are successful in terms of their simplicity and pedagogical purpose ${ }^{11}$, their static analyses disregard relationships between variables over time. For instance, in Lawn (2003), the static equilibrium occults the time lag between monetary and fiscal policies and long-term changes in technological state. Fiscal expansion in his model increases resource costs in the short run. However, the development of new technologies may depend on decades of research. Also, based on thermodynamic analysis of material and energy economic transformations (Georgescu-Roegen, 1971), we could expect that thermodynamic limits to technological efficiency are more evident in the long-run, hindering this kind of adjustment.

\section{Radical uncertainty amplified: fundamentalist post-Keynesian ecological macroeconomics}

The first initiatives of dialogue between ecological economics and post-Keynesian macroeconomics emphasized similarities in their theoretical and methodological framework. Contrary to the neoclassical mainstream economics, realistic hypotheses are essential to both approaches as they make it possible to explain the complex social reality (see Section 3). Thus, excessive formalization in economics was sharply criticized and uncertainty was claimed to be the fundamental concept shared by both schools. Therefore, some ecological economists seemed more likely to share the views with a more fundamentalist post-Keynesian approach.

One important claim made by fundamentalist post-Keynesians is that in a non-ergodic economic environment economists' ability to make predictions is severely limited. This claim was indicated in the Treatise on Probability (Keynes, 1921) and further discussed by many authors mainly headed by Paul Davidson. In this non-ergodic environment, the future is transmutable and uncertain. When agents recognize that they live in a transmutable and uncertain environment, they seek to hold money as a hedge against an unpredictable future. Uncertainty is also behind investment decisions that are taken based on futures expectation of marginal capital efficiency compared with interest rates. The capitalist evaluates his future earnings from buying a capital good (today) hoping that his predictions will stand in the longrun (when the final product is sold) - which is only a possibility, not a guarantee a priori. Under these conditions, uncertainty is implied in the instability of investment - and thus in employment. In these non-ergodic conditions, "it is sensible for decision makers to make choices that would be seen as 'irrational' in an immutable system" (Davidson, 1996, p. 493). The idea of uncertainty is well expressed by Keynes (1937, p. 213-214):

By 'uncertain' knowledge, let me explain, I do not mean merely to distinguish what is known for sure from what is only probable. The game of roulette is not subject, in this

(11) Actually, IS-LM models only exist in macroeconomics textbooks due to their simplicity to explain goods and money markets' interdependence. The IS-LM model was criticized by Hicks (1981) himself. 
sense, to uncertainty; nor is the prospect of a Victory bond being drawn. Or, again, the expectation of life is only slightly uncertain. Even the weather is only moderately uncertain. The sense in which I am using the term is that in which the prospect of a European war is uncertain, or the price of copper and the rate of interest twenty years hence, or the obsolescence of a new invention, or the position of private wealth-owners in the social system in 1970. About these matters, there is no scientific basis on which to form any calculable probability whatever. We just do not know (Emphasis added).

The similarities between this perspective and uncertainty in ecological economics are evident as we can see in an influential paper published by Costanza in the first Ecological Economics' edition:

In the next 20 to 30 years we may begin to hit real fossil fuel supply limits. Will fusion energy or solar energy or conservation or some yet unthought of energy source step in to save the day and keep economies growing? The technological optimists say ye, and the technological pessimists say no. Ultimately, no one knows. Both sides argue as if they were certain, but the most insidious form of ignorance is misplaced certainty (Costanza, 1989, p. 3, Emphasis added).

Post-Keynesians reinforce Keynes' analysis on uncertainty and non-neutrality of money, emphasizing their role in modern economies' vulnerability. Under organized financial markets, entrepreneurs can receive an investment gain without having to wait for it to be realized. This can contribute to speculative investment expansion, but also to its sudden reduction. Minsky's financial instability hypothesis states that, under stable economic growth and financial solidity, agents revaluate their expectations positively, increasing their debt commitments to amplify investments (or even to meet the growing payment commitments). At some point in this ascendant trajectory, the higher costs, mainly of interest rates, change this course, starting the crisis (Minsky, 1977, 2008).

Ecological economists argue that the adoption of the 'precautionary principle' could avoid an environmental crisis. Accordingly, in the absence of scientific certainty, a political and public decision should be guided by precaution. In the face of the uncertainty of ecological economic systems, the researchers working within the field are unable to decide with certainty about a set of axioms and make deductions that are independent of external interference. ${ }^{12}$ If this was the case for Keynes, in ecological economics the uncertainties are amplified because, besides economic uncertainties, we have to deal with unpredictable outcomes of human intervention on nature. Currently, these unpredictable ecological outcomes can be considered as an increasingly relevant component of expectations, thus, requiring institutions to reduce uncertainties and decisions guided by precaution (Berr, 2010).

Holt et al. (2009) published the first relevant initiative promoting a further discussion between both approaches in Post Keynesian and Ecological Economics: confronting environmental issues. The book was composed of fourteen chapters, many of which concerned

(12) This challenge is addressed in post-normal science that offers an approach to manage complex science-related issues characterized by fundamental uncertainty and a plurality of valid perspectives (see Funtowicz; Ravetz, 1994). 
methodological and theoretical issues. Despite the varied subjects, most of the chapters focus on common ground between the schools. Besides similarities in the methodological framework, one important common ground shared by post-Keynesian and ecological economists concern their criticism of neoclassical economics. In the introductory chapter, Holt and Spash (2009) highlight that both approaches criticize mechanistic equilibrium models, the free market as a means to lead to optimal outcomes and assumptions regarding how people behave. On the other hand, some chapters also emphasize differences between the schools, highlighting the post-Keynesian focus on economic growth that contrasts with ecological economic criticism regarding environmental consequences of growth (Spash and Schandl, 2009; Vatn, 2009).

Regarding methodological contributions, Mearmam focuses on realism, ontology, and open systems. Also, his analysis seems to derive from crossing ecological economics with a more fundamentalist post-Keynesianism approach as he criticizes formalism and emphasizes the role of politics. According to Mearman (2009, p. 42), what he calls "Post Keynesian environmental economics" should embrace:

realism; ontological reflection; an ontology of depth, layers and emergence; an ontology of uncertain openness, history and change; a skepticism about current methods, including long chains of deduction, mathematical modeling, econometrics and concepts such as equilibrium and optimization; and a recognition that ordinary logical thought might require weighing different types of evidence drawn from a variety of locations and methods.

Similarly, Vatn (2009) highlights similarities between ecological economics and postKeynesianism at the ontological level, as both embrace 'organicist' ontology. Like postKeynesians, ecological economists perceive the world as non-ergodic, composed of open ecological and social systems, whose historical trajectories are subjected to irreversibility. Again, the critical concepts behind these ontological perspectives are complexity and uncertainty, whether in human interactions or ecological and economic systems. Nevertheless, the kind of uncertainty emphasized by both schools is the same - i.e., "Knightian uncertainty whether it is termed radical uncertainty, fundamental uncertainty or irreducible ignorance" (Vatn, 2009, p. 125) ${ }^{13}$.

In this view, ecological macroeconomics would only work with an analytical model in contrast to more detailed numerical models that could generate forecasts and allow different scenarios to be analyzed ${ }^{14}$. One such analytical ecological macroeconomic model was developed by Fontana and Sawyer $(2013,2016)$. Their model was based on the former Keynesian view of the economy, demand-led growth and fundamental uncertainty, although it

(13) Although, rigorously, there can be differences between them. For instance, Dequech (2007, p. 287) argue that Knightian uncertainty should be called ambiguity. It is interesting to note that these ecological economists seem to agree with the fundamental kind of uncertainty as defined by Dequech (2011).

(14) Hardt and O'Neill (2017) also distinguish these two types of models (analytical and numerical) in ecological macroeconomics. 
also relied upon a Kaleckian approach. They seek to revaluate macroeconomic analyses and policies in light of environmental consequences of economic growth, despite their social role in alleviating high and persistent levels of unemployment. In their analysis, while economic growth is demand-driven through investment and credit creation, environmental and ecological constraints are supply constraints to growth. Also, as market forces are not expected to allow the economy to remain within these constraints, government policies and social norms are central to making output growth environmentally sustainable. For instance, "government policies and social norms could be usefully used to modify the behavior of banks, financial institutions and borrowers in a way to affect investments and consumption in the economy toward a more sustainable long-run perspective" (Fontana; Sawyer, 2013, p. 263).

Fontana and Sawyer $(2013,2016)$ adopt the strong sustainability hypothesis - i.e., that considers a limited substitution of natural resources for physical and human capital. This hypothesis is in line with the ecological economic approach and implies a 'fixed factor proportions' production function, contrasting with the Cobb-Douglas function used in neoclassical economics. Without substitution between factors, there is no possibility of a natural market adjustment that could lead to a 'natural rate of growth.' The authors identify three different growth rates: i) growth of capital stock (demand-led growth rate); ii) growth of labour resources in 'efficiency units' (supply-led growth rate); and iii) sustainable growth rate of the "ecological footprint" ${ }^{15}$, or the sustainable depletion rate of natural capital (nature-led growth rate). Indeed, market forces are not able to align these different growths rates. If the growth rate is demand-driven, a low level of unemployment or a sustainable growth rate are not assured. Thus, under the lack of market adjustment and to avoid a catastrophic 'adjustment' to this sustainable rate, a complex and multifaceted set of public policies is required. Finally, Fontana and Sawyer (2016, p. 193) assert that "path-dependence, uncertainty and financial instability all call for a cautious approach when trying to predict the emergence of a sustainable rate of growth of output."

What is not clear, not only in Fontana and Sawyer, is what kind of "cautious approach" ecological macroeconomics should embrace to deal with ecological, economic and financial uncertainty and instability. Indeed, it seems that this more fundamentalist post-Keynesian approach is methodologically consistent, although less likely to provide precise responses to this very complex challenge ${ }^{16}$. As ecological macroeconomics moves from a more straightforward mainstream approach, which only considered biophysical limits, to an approach methodologically more consistent with its ontological bases, it may have to deal with increasing complexity. In other words, it is necessary to reflect on the advantages and

(15) The 'ecological footprint' is defined according to Wackernagel and Rees (1996). Possibly, the sustainable growth rate of the ecological footprint is zero or negative (Fontana; Sawyer, 2013, p. 257).

(16) The macroeconomic analysis, in this case, should be based on some "historical model" like the one presented by Paul Davidson (1978). 
disadvantages of maintaining the "maximum level of generality"17 or adding additional restrictive axioms to work on a high level of abstraction.

\section{From system thinking to complex post-Keynesian ecological macro dynamics}

Røpke (2016, p. 237-238) claims that "system thinking is characteristic of ecological economics" and that "it is useful for analytical purposes to approach the complex reality with a system perspective". A system can be characterized by an interconnected set of elements with particular functions and mechanisms that may guarantee its perpetuation. Also, a system's structure may present complex behaviour not manifested in its isolated elements. Finally, systems are often hierarchically organized, so that sub-systems can be aggregated in larger subsystems. This very brief description shows many similarities with ecological economic subjects: ecological and economic systems and interaction among them are better characterized by their complex interaction than linear modes of causality or isolated elements analysis.

Therefore, not surprisingly, systems modeling also contributes to ecological macroeconomic development. For instance, Jackson et al. (2014, p. 16) assert that "systems modeling has a long pedigree within ecological economics" - a pioneer used in The Limits to Growth (Meadows et al., 1972). Similarly, Victor's (2008) LowGrow model for the Canadian economy works with economic, social and environmental variables in different systems and explores their complex and dynamical relation in time. In comparison to Meadowns et al. (1972), Victor's model presents a more significant concern with relationships and specifications of economic variables. However, its economic system is partly based on conventional macroeconomics. For instance, the aggregated supply is represented by a CobbDouglas function, allowing continuous substitution between input factors. ${ }^{18}$ Also, the model does not capture the financial aspects of the economy as emphasized by post-Keynesians.

In the post-Keynesian perspective, dynamic macroeconomic models have been the focus of authors inspired by Kalecki (1935, 1971), Kaldor (1940) and Goodwin (1951). These models often contain nonlinear economic relations and complex endogenous fluctuations. Rosser Jr. (2009, 2010) claims that complexity theory is consistent with Keynesian ontological foundations and also with a more heterodox ecological economics. On the one hand, complexity underlies Keynesian uncertainty - although Davidson (1996) argues that systems' complexity in an uncertain context cannot be reduced to a nonlinear equation system. On the other, ecological economic system dynamics are characterized by their complexity. Therefore, ecological macroeconomic dynamics would not only encompass complexity but also a fundamental kind of uncertainty derived from its systems - e.g., when analysing environmental impacts from human activity, ecological thresholds are unknown.

(17) We are referring to Davidson (2005, p .400): "Keynes's theory has the maximum level of generality, because, as Keynes indicated, it has fewer restrictive axioms than any classical theory currently existing."

(18) This limitation is addressed by Victor (2008, p. 190). 
Rezai, Taylor and Mechler (2013) advocate a demand-driven model for ecological macroeconomics based on a system perspective of natural and socio-economic interrelations. Hence, this model could embrace not only Keynesian concerns about involuntary unemployment but also address ecological economic issues such as sustainable consumption, reduced working time and "green" investment. Based on such issues and their economic effects on climate change, the authors argue that a post-Keynesian macroeconomic analysis with key environmental variables provide counterintuitive results and thus important information about economic and environmental policies. For instance, it is interesting to note what they call the "demand-driven version of the rebound effect": in a demand-driven world, an increase in mitigation expenditure (e.g., the building of windmills) increases output and carbon emission. This would not occur in a neoclassical model of full employment: "In an optimal growth model, the level of output and associated emissions are fixed in each unit of time. The optimizing agent only decides on the composition of the expenditure basket (consumption, investment, and mitigation)" (Rezai et al., 2013, p. 74). Despite not providing a complete ecological macroeconomic model, Rezai et al. (2013, p. 74) identify "the building blocks of a (more) complete model" based on the interaction of output, labour, productivity, employment, energy use and carbon emissions. Also, this dynamical model would be complex and contain feedback between its variables.

Further development of this initial post-Keynesian model is presented in Taylor et al. (2016) through the introduction of biophysical limits - represented by atmospheric greenhouse gas (GHG) concentration - in a Kaleckian model ${ }^{19}$. Under this perspective, the accumulation process is inherently unstable due to the irregular nature of the investment. Investment, simultaneously, increases national wealth and amplifies production capacity, reducing the rate of capacity utilization and profitability. In Taylor et al. (2016), atmospheric GHG concentration can also generate system instability: capital accumulation increases GHG concentration, which in turn can reduce capital over time. The interaction between these variables (expressed as the capital/population ratio, $\mathrm{K} / \mathrm{N}$, and the $\mathrm{GHG} /$ capital ratio, $\mathrm{G} / \mathrm{K}$ ) is analysed in a two-dimensional dynamical system. It shows that in an initial steady-state condition, in which $\mathrm{K} / \mathrm{N}$ is constant and $\mathrm{G} / \mathrm{K}$ is stable or falling, a perturbation in the system changes the steady-state, but the variables may not converge toward it. ${ }^{20}$ These dynamics are mostly different from Sim's IS-

(19) The Kaleckian analysis of income distribution between wages and profits may also be necessary for ecological macroeconomists. Once ecological economics admits the existence of limits to growth, the issue of income distribution becomes very relevant. Therefore, besides the understanding of complex systems, this post-Keynesian strand can also offer ecological economics essential insights into growth and distribution (Kronenberg, 2010).

(20) The instability of the model is produced by the ambiguous effect of $\mathrm{K} / \mathrm{N}$ changes in $\mathrm{G} / \mathrm{K}$. Notably, the effects of an increase of $\mathrm{K} / \mathrm{N}$ in $\mathrm{G} / \mathrm{K}$ growth are not clear. Raising $\mathrm{K} / \mathrm{N}$ makes $\mathrm{G}$ increase, but also makes $\mathrm{K}$ increase; thus, the effect in $\mathrm{G} / \mathrm{K}$ will depend on the increasing size of each variable. If higher values of $\mathrm{K} / \mathrm{N}$ make $\mathrm{G} / \mathrm{K}$ increase, a cyclical behavior may follow. In this case, the variables may converge to a quasi-steady state with higher levels of income, and lower levels of GHG provided that appropriate climate change mitigation policies be introduced. However, if higher values of $\mathrm{K} / \mathrm{N}$ make $\mathrm{G} / \mathrm{K}$ decrease, there is a destabilizing positive feedback between the variables, and there are divergent trajectories that depend on their initial conditions. To better understand these dynamics "future research would have to be studied in numerical calibration and simulation (...) due to the model's complexity" (Taylor et al., 2016, p.203). Moreover, we could add two other limitations to the model application: i) the uncertainty in GHG measurement and ii) the impossibility to measure the aggregate capital $(\mathrm{K})$ of an economy with heterogeneous machines. This last limitation is known as the Cambridge Controversy (see Cohen and Harcourt, 2003). 
LM-EE model, in which interaction between environmental damage and investment produces one macro-environmental equilibrium through a natural adjustment mechanism.

Although the previous model provides interesting insights into the macro dynamics of ecological economics, it detracts from financial issues. The models' instabilities result from the interaction between GHG emission and economic variables. Introducing the financial system in ecological macro dynamics may significantly amplify the complexities and instability of ecological macroeconomic analysis. However, this may be crucial to understanding the modern economy, recent crises and economic growth (see Section 5). Aware of this, Jackson and Victor also analysed ecological macroeconomics based on post-Keynesian insights. The authors aimed to build a "stock-flow consistent (SFC) ecological macroeconomics" (Jackson et al., 2014, p. 16). For this purpose, they constructed two distinct models: Financial Assets and Liabilities in a Stock and Flow consistent Framework (FALSTAFF) and Green Economy Macro-Model and Accounts framework (GEMMA).

GEMMA is composed of a system dynamics input-output model with twelve industry sectors and six accounting sectors that provides a detailed representation of real economy. The input-output model specifies the transactions across industrial sectors and between sectors and final consumers (households, government expenditures, exports, etc.). However, despite the possibility of analysing specific sectors transactions - including scenarios for the decarbonization of the economy -, GEMMA did not offer a complete ecological macroeconomic approach. According to Jackson and Victor (2015b, p. 10), the GEMMA framework "so far lacks a full articulation of the SFC approach of post-Keynesian economics and modern money theory". More detailed financial elements and a consistent approach for ecological macroeconomics were explored by Jackson and Victor (2015a) based on SFC macroeconomics, although the integration of the model with an ecological subsystem is still to be consolidated ${ }^{21}$.

The SFC approach is identified by Lavoie (2009) as a possible locus for the reconciliation between fundamentalist post-Keynesians' and other post-Keynesian strands. Post-Keynesian SFC models "are a specific kind of post-Keynesian macro model that follows distinctive accounting rules, ensuring the consistent integration of the stocks and flows of all the sectors of the economy" (Caverzasi; Godin, 2015, p. 160). They make it possible to integrate into one unique model monetary issues emphasized by the fundamentalist strand money, debt, liquidity, etc. - and many aspects of the real economy analysed by other postKeynesians, such as income distribution, rates of capacity utilization, profit rates, etc. (Lavoie, 2009). Furthermore, the SFC approach provides an alternative to fundamentalist postKeynesian disbelief in macroeconomic predictions due to the non-ergodicity: it legitimates the study of medium-run dynamics by linking short periods in which stocks generate flows which

(21) This integrated model is developed by Naqvi (2015) in the ECOGRO model, which combines production, consumption, and emission in a SFC framework. 
update these stocks, that in turn generate new flows and so on (Macedo and Silva; Dos Santos, 2009).

The latter point might have vital importance for consistent ecological macroeconomics, since this emerging approach is concerned with future sustainable scenarios and trajectories. Assuming radical uncertainty about the future - i.e., that investment decisions are taken in an uncertain context and produce uncertain effects on ecological systems - not only makes it harder to accept neoclassical models based on the long-run equilibrium but also could hinder economic forecasting. In mainstream macroeconomic models, free market forces generate optimum results in the long-run, even in the case of unemployment and recession in the shortrun. In contrast, fundamentalist post-Keynesians tend to restrict their analysis to short-run periods due to the instability of long-run investments. However, "how can one formulate and legitimate normative judgments without an apparatus that allows the setting up of scenarios where their future implications unfold?" (Macedo and Silva; Dos Santos, 2009, p. 108). The SFC approach provides a "middle ground" between preventing scenario predictions and accepting mainstream long-run equilibrium as it links the dynamics of flows and stocks of many short periods.

Jackson and Victor (2015a, p. 33) analyse whether a "debt-based money creates a growth imperative" based on the SFC approach by testing "the ability of the model to provide for a stationary state ${ }^{22}$. This is an intriguing and important endeavour because ecological economists based on Frederick Soddy (1933) as a rule associate the obligation of paying debts created by the financial system with real economic growth imperative. Following the postKeynesian literature, the authors define the stationary state as the one in which there is zero GDP growth - i.e. "stocks and flows do not change over time"; while the steady state is the one in which stocks and flows "grow at the same rate" (Caverzasi; Godin, 2015, p. 165). To create an artificial economy representing an actual modern economy in a stationary state, the models' parameters are calibrated. Jackson and Victor (2015a, p. 35-39) look for "one reasonable stationary state solution" from values that could describe "an advanced western economy" - notably, UK and Canada. Indeed, under a specific variable behavioural hypothesis and with a specific set of initial values, the stationary state is possible even within a creditbased money system.

In the simplest scenario, this stationary state occurs when the initial value for gross investment $\left(\mathrm{I}_{0}\right)$ in productive capital is equal to the initial depreciation $\left(\delta_{0}\right)$. Also, the initial value for government expenditure $\left(\mathrm{G}_{0}\right)$ added to government bonds interest $\left(\mathrm{r}_{\mathrm{B}} \mathrm{B}_{0}\right)$ equals the initial household income tax $\left(\mathrm{T}_{0}\right)$ : i) $\mathrm{I}_{0}=\delta_{0}$, and ii) $\mathrm{G}_{0}+\mathrm{r}_{\mathrm{B}} \mathrm{B}_{0}=\mathrm{T}_{0}$. Namely, the net accumulation of the productive capital is zero, and the government achieves fiscal balance. Moreover, the behavioural relationship in the model determines that profits (net of depreciation) are entirely

(22) “Jackson and Victor (2016) employ a simplified version of this model to test Piketty's hypothesis that slow economic growth increases inequality (see Piketty, 2014). Their main result is that "rising inequality is by no means inevitable, even in the context of declining growth rates" (Jackson; Victor, 2016, p. 217). 
distributed as dividends to households (assumed to be the sole equity owners). From previous initial values, we also know that the net lending of all other sectors (government, firms, and banks) is equal to zero. Finally, the authors also set the households' net lending equal to zero: iii) $\mathrm{NL}_{0}{ }^{\mathrm{h}}=0$. Namely, households' savings is zero and their disposable income is consumed ${ }^{23}$. Since net lending is equal to zero for all five sectors, the net financial worth of all sectors remains unchanged during the period.

The stock-flow-fund ecological macroeconomics model by Dafermos et al. (2017) advances in the development of a macroeconomics that takes into account the ecological economics foundations, by integrating the SFC approach with Georgescu-Roegen's flow-fund model. The latter is based on Georgescu-Roegen's critique of the characteristics of the production process as defined by the neoclassical approach, which ignores the different roles displayed by each production factor. On the one hand, the fund-services resources, as the agents of transformation (such as capital, land, and labor), are not embodied in the output produced. On the other hand, the stock-flow resources are either physically incorporated into the final products or transformed into waste. These differences reinforce precisely one of the most important propositions of ecological economics: qualitative differences between the production factors make them unsubstitutable. In the ecological macroeconomics model, the distinction between stock-flow and fund-service resources is covered by a physical input-output framework, in which depletion problems affect the stock-flow resources (exhaustion of resources) and degradation problems (accumulation of waste and pollution) damage the fundservices resources.

One fundamental question that emerges from this kind of model is if they provide a consistent basis for analysing desirable scenarios of a stationary state, supporting the discussion on policy proposals. Certainly, SFC models are an interesting tool for analysing long-run economic scenarios, as they also integrate the real and the financial aspects of the economy. However, evidently, they require some simplifying and unrealistic hypothesis. For instance, FALSTAFF calibration is not consistent with Minsky's financial instability hypothesis which states that the economies are endogenously unstable ${ }^{24}$. Moreover, they are based on simplified economic structures - the stock-flow-fund ecological macroeconomic model by Dafermos et al. (2017), for instance, was built without a government sector. Thus, the economy described by SFC models will always be "at best a useful caricature of some general features of actual capitalist economies" (Dos Santos, 2006, p. 561). As to provide enough elements for a discussion on policy-making, ecological macroeconomics should not only look for suitable formal models but also study the several specificities of each context. Therefore, we believe that the efforts to develop a post-Keynesian ecological macro dynamic, even when based on sophisticated SFC models, are not exempt from an appropriate institutional, historical and

(23) Household savings are determined by the balance between income - wages, dividends and (net) interest from banks - and spending - consumption and taxes.

(24) This limitation is emphasized by Jackson and Victor (2015, p. 46). 
political analysis of each specific context and should emphasize the role and the limits of modeling scenarios.

\section{Concluding remarks}

The objective of this paper was to organise the debate surrounding ecological macroeconomics and point out the importance of methodological criticism for its development. Ecological macroeconomics is an emerging macroeconomic approach from a relatively recent area of study. If there are significant divergences within ecological economics about the extent and the meaning of methodological pluralism, we could not expect less controversy in the development of ecological macroeconomics. Indeed, we presented a very eclectic set of initiatives in the area, sometimes based on contrasting assumptions and theories. On the one hand, we believe that this great diversity can be inspiring and bring innovative ideas and questions to the field. On the other, we could argue that "diversity, which is just another term for pluralism, only leads to growth if it is accompanied by criticism" (Caldwell, 1989, p. 56). That is, consistent ecological macroeconomics cannot avoid choosing whether assumptions and macroeconomic theories prove to be better in light of ecological economic foundations. Given this wide range of emerging strands, accepting all the new initiatives would not only make the development of a new approach useless and meaningless but would also be ontologically inconsistent. At the opposite extreme, the exclusion of certain approaches cannot occur without proper reflection on the foundations and relevant issues of ecological economics. Until then, even when there is some delimitation of the area - as already discussed concerning Hardt and O'Neil's (2017) initiative of excluding neoclassical models - the criteria are not discussed enough, making them seem somewhat arbitrary. In this sense, methodological criticism must take place in discussions on ecological macroeconomics, which may be a central step for the consolidation of a relevant new approach to macroeconomics.

Even if the arguments presented are not intended to be definitive, some final considerations about possible directions for ecological macroeconomics are presented with the objective of fomenting the debate. First, it is clear that the delimitation of an economically sustainable scale, in which material and energy use is within ecological limits, must be one of the central concerns of ecological macroeconomics. However, as the analysis of "mainstream" ecological macroeconomics indicated, it is probably not enough since ecological economics was also consolidated on other relevant bases. That brings us to the second point: even the biophysical limits require, as to be understood and analyzed, an approach capable of dealing with the ecosystem's complexities, which also involve the risk of irreversible catastrophic ruptures. When analyzing the macroeconomic effects of such limits or suggesting policies to deal with them, ecological macroeconomics may have to consider a non-ergodic world with historical and irreversible trajectories similar to that carried out by some post-Keynesian approaches. This is one of the reasons why the dialogue between ecological economists and post-Keynesians can indeed prove very promising. Finally, the most recent contributions based on stock-flow consistent models have made it possible to predict future scenarios without 
Beatriz Macchione Saes, Ademar Ribeiro Romeiro

accepting mainstream long-run equilibrium. Emphasizing the limits and major simplification of these scenarios and not neglecting the historical, political and institutional analysis, ecological macroeconomic models can shed light on the unsustainability of current macroeconomics and possibly contribute to the discussion on the environmental challenges posed.

\section{References}

ANDERSON, B.; M'GONIGLE, M. Does ecological economics have a future? Contradiction and reinvention in the age of climate change. Ecological Economics, v. 84, p. 37-48, 2012.

ANDRADE, D. C.; GARCIA, J. R. Estimating the Genuine Progress Indicator (GPI) for Brazil from 1970 to 2010. Ecological Economics, v. 118, p. 49-56, 2015.

BERR, E. Keynes and sustainable development. International Journal of Political Economy, v. 38, n. 3, p. 22-38, 2009.

CALDWELL, B. J. Beyond positivism: economic methodology in the twentieth century. London and New York: Routledge, 1994.

CALDWELL, B. J. Does methodology matter? How should it be practiced? Finnish Economics Papers, v. 3, n. 1, p. 64-71, 1990.

CALDWELL, B. J. Post-Keynesian methodology: as assessment. Review of Political Economy, v. 1, p. 43-64, 1989.

CAVERZASI, E.; GODIN, A. Post-Keynesian stock-flow consistent modeling: a survey, Cambridge Journal of Economics, v. 39, p. 157-187, 2015.

COHEN, A. J.; HARCOURT, G. C. Whatever happened to the Cambridge Capital Theory Controversies? Journal of Economic Perspectives, v. 17, 2003.

COSTANZA, R. Ecological economics: a research agenda. Structural Change and Economic Dynamics, v. 2, n. 2, p. 335-357, 1991.

COSTANZA, R. What is ecological economics? Ecological Economics, v. 1, 1-7, 1989.

DAFERMOS, Y.; NIKOLAIDI, M.; GALANIS, G. A stock-flow-fund ecological macroeconomic model. Ecological Economics, v. 131, p. 191-207, 2017.

DALY, H. E.; FARLEY, J. [2004]. Ecological economics: principles and applications. $2^{\text {nd }}$ ed, Washington: Island Press, 2011.

DALY, H. E. Towards an environmental macroeconomics. Land Economics, v. 67, n. 2, p. 255-259, 1991.

DAVIDSON, P. Responses to Lavoie, King, and Dow on what Post Keynesianism is and who is a Post Keynesian. Journal of Post Keynesian Economics, v. 27, n. 3, p. 393-408, 2005. 
DAVIDSON, P. Reality and economic theory. Journal of Post Keynesian Economics, v. 18, n. 4, summer, p. 479-508, 1996.

DAVIDSON, P. Money and the real world. $2^{\text {nd }}$ ed. London: Macmillan, 1978.

DECKER, S.; WOHAR, M. E. Substitutability or complementarity? Re-visiting Heyes' ISLM-EE model. Ecological Economics, v. 74, p. 3-7, 2012.

DEQUECH, D. Uncertainty: a typology and refinements of existing concepts. Journal of Economic Issues, v. XLV, n. 3, p. 621-640, 2011.

DEQUECH, D. Neoclassical, mainstream, orthodox, and heterodox economics, Journal of Post Keynesian Economics, v. 30, n. 2, p. 279-302, 2007.

DOS SANTOS, C.H. Keynesian theorizing during hard times: stock-flow consistent models as an unexplored 'frontier' of Keynesian macroeconomics. Cambridge Journal of Economics, v. 30, n. 4, p. 541-565, 2006.

DOW, S. C. Axioms and Babylonian thought: a reply. Journal of Post Keynesian Economics, v. 27, n. 3, p. 385-391, 2005.

DOW, S. C. Methodological pluralism and pluralism of method. In: SALANTI, A.; SCREPANTI, E. (Ed.). Pluralism in economics: new perspectives in history and methodology. Aldershot: Edward Elgar, 1997. p. 89-99.

DOW, S. C. Macroeconomics thought: a methodological approach. Oxford, New York: Basil Blackwell, 1985.

ECOLOGICAL Economics. Ecological macroeconomics: special section, v. 121, p. 181-253, 2016.

ECOLOGICAL Economics. The contribution of Nicholas Georgescu-Roegen: special issue, v. 22, 1997.

FEYERABEND, P. K. Against method: outline of an anarchistic theory of knowledge. London: New Left Books, 1975.

FEYNMAN, C. The character of physical law. Cambridge, MA: MIT Press, 1965.

FONTANA, G.; SAWYER, M. Towards post-Keynesian ecological macroeconomics. Ecological Economics, v. 121, p. 186-195, 2016.

FONTANA, G.; SAWYER, M. Post-Keynesian and Kaleckian thoughts on ecological macroeconomics. European Journal of Economics and Economic Policies: Intervention, v. 10, n. 2, p. 256-267, 2013.

FRIEDMAN, M. The methodology of positive economics. In: FRIEDMAN, M. (Ed.). Essays in positive economics. Chicago: Chicago University Press, 1953. 
Beatriz Macchione Saes, Ademar Ribeiro Romeiro

FUNTOWICZ, S. O.; RAVETZ J. The worth of a songbird: ecological economics as a postnormal science. Ecological Economics, v. 10, p. 197-207, 1994.

GEORGESCU-ROEGEN, N. The entropy law and the economic process. Cambridge: Harvard University Press, 1971.

GOODWIN, R. M. The nonlinear accelerator and the persistence of business cycles. Econometrica, v. 19, p. 1-17, 1951.

GOWDY, J.; ERICKSON, J. Ecological economics at a crossroad. Ecological Economics, v. 53, p. 17-20, 2005.

HAMOUDA, O. F.; HARCOURT, G. C. Post Keynesianism: from criticism to coherence. Bulletin of Economic Research, v. 40, n. 1, p. 1-33, 1988.

HARDT, L.; O'NEILL, D. W. Ecological macroeconomic models: assessing current developments. Ecological Economics, v. 134, p. 198-211, 2017.

HARRIS, J. M. Ecological macroeconomics: consumption, investment, and climate change. Global Development and Environmental Institute, 2008. (Working Paper, n. 08-02).

HEYES, A. A proposal for the greening of textbook macro: 'IS-LM-EE'. Ecological Economics, v. 32, p. 1-7, 2000.

HICKS, J. R. IS-LM: an explanation. Journal of Post Keynesian Economics, v. 3, n. 2, p. 139154, 1981.

HICKS, J. R. Value and capital. Oxford: Clarendon Press, 1939.

HICKS, J. R. Mr. Keynes and the "classics": a suggested interpretation. Econometrica, v. 5, n. 2, p. 147-159, 1937.

HODGSON, G. On the problem of formalism in economics. In: FULLBROOK, E. (Ed.). Ontology and economics. Tony Lawson and his critics. London and New York: Routledge, 2009.

HOLT, R. P. F.; PRESSMAN, S. E.; SPASH, C. (Ed.). Post Keynesian and ecological economics. Confronting environmental issues. Cheltenham: Edward Elgar, 2009.

HOLT, R. P. F.; SPASH, C. L. Post Keynesian and ecological economics: alternative perspectives on sustainability and environmental economics. In: HOLT, R. P. F.; PRESSMAN, S.; SPASH, C. L. (Ed.). Post Keynesian and ecological economics: confronting environmental issues. Cheltenham: Edward Elgar, 2009. p. 3-24.

JACKSON, T. Prosperity without growth: economics for a finite planet. London: Sterling, VA, Earthscan, 2009.

JACKSON, T.; DRAKE, B.; VICTOR, P.; KRATENA, K.; SOMMER, M. Foundations for an ecological macroeconomics: literature review and model development. Workpackage 205, 
Ecological macroeconomics: a methodological review

Milestone 38, Welfare Wealthy Work for Europe Project. Vienna: WIFO, 2014. (Working Paper, n. 65).

JACKSON, T.; VICTOR, P. Does slow growth lead to rising inequality? Some theoretical reflections and numerical simulations. Ecological Economics, v. 121, p. 206-219, 2016.

JACKSON, T.; VICTOR, P. Does credit create a 'growth imperative'? A quasi-stationary economy with interest-bearing debt. Ecological Economics, v. 120, p. 32-48, 2015 a.

JACKSON, T.; VICTOR, P. Towards a stock-flow consistent ecological macroeconomics. An overview of the FALSTAFF framework with some illustrative result. UNEP Inquiry/CIGI Research Convening United Nations Environment Programme, 2015b. (Inquiring working paper 15/04).

JACKSON, T.; VICTOR, P. Productivity and work in the 'green economy' - Some theoretical reflections and empirical tests. Environmental Innovation and Societal Transitions, v. 1, p. 101-108, 2011.

KALDOR, N. A model of the trade cycle. The Economic Journal, v. 50, p. 78-92, 1940.

KALECKI, M. A macrodynamic theory of business cycles. Econometrica, v. 3, p. 327-344, 1935.

KALECKI, M. Selected essays on the dynamics of the capitalist economy. Cambridge: Cambridge University Press, 1971.

KALLIS, G.; MARTINEZ-ALIER, J. and NORGAARD, R.B., 2009. Paper assets, real debts: $\mathrm{Na}$ ecological-economic exploration of the global economic crisis, Critical perspectives on international business, v. 5, no. 1, 14-25

KEYNES, J.M. The general theory of employment. Quarterly Journal of Economics, v. 51, p. 209-223, 1937.

KEYNES, J. M. The general theory of employment, interest and money. London: Macmillan Press, 1936.

KEYNES, J. M. A treatise on probability. London: Macmillan, 1921.

KRONENBERG, T. Finding common ground between ecological economics and postKeynesian economics. Ecological Economics, v. 69, p. 1488-1494, 2010.

LAVOIE, M. Post-Keynesian economics: new foundations. Cheltenham, Northampton: Edward Elgar, 2014.

LAVOIE, M. Towards a post-Keynesian consensus in macroeconomics: reconciling the Cambridge and Wall Street views. In: HEIN, E.; NIECHOJ, T.; STOCKHAMMER, E. (Ed.). Macroeconomic policies on shaky foundations: wither mainstream economics? Marburg: Metropolis Verlag, 2009. p.75-99. 
Beatriz Macchione Saes, Ademar Ribeiro Romeiro

LAWN, P. A. On Heyes' IS-LM-EE proposal to establish an environmental macroeconomics, Environment and Development Economics, v. 8, 31-562003.

LAWSON, T. Reorienting economics. London, Routledge2003.

LUCAS, R.E. and SARGENT, T.J. After Keynesian macroeconomics, Federal Reserve Bank of Minneapolis Quarterly Review, v. 3, no. 2, 1-161978.

MACEDO AND SILVA, A.C. and DOS SANTOS, C.H. Peering over the edge of the short period? The Keynesian roots of stock-flow consistent macroeconomic models, Cambridge Journal of Economics, v. 35, 105-1242011.

MAYUMI, K. The Origins of ecological economics. The bioeconomics of Georgescu-Roegen. London and New York: Routledge, 2001.

MEARMAN, A. Recent developments in post Keynesian methodology and their relevance for understanding environmental issues. In: HOLT, R. P. F.; PRESSMAN, S. E.; SPASH, C. (Ed.). Post Keynesian and ecological economics. Confronting environmental issues. Cheltenham: Edward Elgar, 2009.

MEADOWS, D.; MEADOWS, D.; RANDERS, J.; BEHRENS III, W. The limits to growth. New York: Universe Books, 1972.

MINSKY, H. P. Stabilizing an unstable economy. New York: McGraw-Hill, 2008.

MINSKY, H. P. The financial instability hypothesis: an interpretation of Keynes and an alternative to 'standard' theory. Nebraska Journal of Economics and Business, v. 16, n. 1, p. 5-16, 1977.

MODIGLIANI, F. Liquidity preference and the theory of interest and money, Econometrica, v. 12, p. 45-88, 1944.

MORAES, G. I.; SERRA, M. A. O Modelos IS-LM-EE para economias abertas e distinções dos efeitos para as economias nacionais. Economia e Sociedade, v. 20, n. 1(41), p. 53-78, 2001 .

NAQVI, A. Modeling growth, distribution, and the environment in a stock-flow consistent framework. Welfare Wealthy Work for Europe Project, WIFO, Vienna, 2015. (Policy Paper, n. 18).

NORGAARD, R. B. The case for methodological pluralism. Ecological Economics, v. 1, p. 37-57, 1989.

PATINKIN, D. Money, interest and prices. $2^{\text {nd }}$ ed. New York: Harper \& Row, 1956.

PATINKIN, D. Price flexibility and full employment. The American Economic Review, v. 38, p. 543-564, 1948.

PIKETTY, T. Capital in the 21st Century. Cambridge, MA: Harvard University Press, 2014. 
REZAI, A.; STAGL, S. Ecological macroeconomics: introduction and review. Ecological Economics, v. 121, p. 181-185, 2016.

REZAI, A.; TAYLOR, L.; MECHLER, R. Ecological macroeconomics: an application to climate change. Ecological Economics, v. 85, p. 69-76, 2013.

ROCKSTRÖM, J.; STEFFEN, W.; NOONE, K.; PERSSON, A.; CHAPIN, F. S.; LAMBIN, E. R.; LENTON, T. M.; SCHEFFER, M.; FOLKE, C.; SHELLNHUBER, H. J.; NYKVIST, B.; WIT, C. A.; HUGHES, T.; VAN DER LEEUW, S.; RODHE, H.; SÖRLIN, S.; SNYDER, P. K.; COSTANZA, R.; SVEDIN, U.; FALKENMARK, M.; KARLBERG, L.; CORELL, R. W.; FABRY, V. J.; HANSEN, J.; WALKER, B.; LIVERMAN, D.; RICHARDSON, K.; CRUTZEN, P.; FOLEY, J. A safe operating space for humanity, Nature, v. 461, p. 472-475, 2009.

RØPKE, I. Complementary system perspectives in ecological macroeconomics - The example of transition investments during the crisis. Ecological Economics, v. 121, p. 237-245, 2016.

RØPKE, I. Ecological macroeconomics: implications for the roles of consumer-citizens. In: COHEN, M.J.; BROWN, H. S.; VERGRAGT, P. J. (Ed.). Innovations in sustainable consumption. New economics, socio-technical transitions and social practices. Cheltenham: Edward Elgar, 2013. p. 48-64.

RØPKE, I. Trends in the development of ecological economics from the late 1980s to the early 2000s. Ecological Economics, v. 55, n. 2, p. 262-290, 2005.

ROSSER JR., J. B. Post-Keynesian perspectives and complex ecologic-economic dynamics. Metroeconomica, v. 62, n. 1, p. 96-121, 2010.

ROSSER JR., J. B. Theoretical and policy issues in complex post Keynesian ecological economics. In: HOLT, R. P. F.; PRESSMAN, S.; SPASH, C. L. (Ed.). Post Keynesian and ecological economics: confronting environmental issues. Cheltenham: Edward Elgar, 2009. p. 221-236.

SCHNEIDER, F.; KALLIS, G.; MARTINEZ-ALIER, J. Crisis or opportunity? Economic degrowth for social equity and ecological sustainability. Introduction to this special issue. Journal of Cleaner Production, v. 18, n. 6, p. 511-518, 2010.

SILVA, M. C. E.; TEIXEIRA, A. A. C. A bibliometric account of the evolution of EE in the last two decades: is ecological economics (becoming) a post-normal science? Ecological Economics, v. 70, p. 849-862, 2011.

SIM, N. C. S. Environmental Keynesian macroeconomics: some further discussion. Ecological Economics, v. 59, p. 401-405, 2006.

SODDY, F. [1926]. Wealth, virtual wealth and debt: the solution of the economic paradox. New York: E.P. Dutton \& C., 1933. 
Beatriz Macchione Saes, Ademar Ribeiro Romeiro

SÖDERBAUM, P. Sustainability economics as a contested concept. Ecological Economics, v. 70, p. 1019-1020, 2011.

SOLOW, R. The economics of resources or the resources of economics, Richard T. Ely Lecture. The American Economic Review, Pittsburgh, The American Economic Association, v. 64, n. 2, p. 1-14, 1974.

SPASH, C. L. New foundations for ecological economics. Ecological Economics, v. 77, p. 3647, 2012.

SPASH, C. L.; SCHANDL, H. Challenges for post Keynesian growth theory: utopia meets environmental and social reality. In: HOLT, R. P. F.; PRESSMAN, S.; SPASH, C. L. (Ed.). Post Keynesian and ecological economics: confronting environmental issues. Cheltenham: Edward Elgar, 2009. p. 47-76.

STIGLITZ, J. E. A neoclassical analysis of the economics of natural resources. In: SMITH, V. K. (Ed.). Scarcity and growth reconsidered. Baltimore, MD: John Hopkins University Press, 1979.

TAYLOR, L.; REZAI, A.; FOLEY, D. K. An integrated approach to climate change, income distribution, employment, and economic growth. Ecological Economics, v. 121, p. 196-205, 2016.

URHAMMER, E.; RØPKE, I. Macroeconomic narratives in a world of crises: an analysis of stories about solving the system crisis. Ecological Economics, v. 96, p. 62-70, 2013.

VAN DEN BERGH, J. C. J. M. Relax about GDP growth: implications for climate and crisis policies. Journal of Cleaner Production, v. 18, n. 6, p. 540-543, 2010.

VATN, A. Combining post Keynesian, ecological and institutional economics perspective. In: HOLT, R. P. F.; PRESSMAN, S.; SPASH, C. L. (Ed.). Post Keynesian and ecological economics: confronting environmental issues. Cheltenham: Edward Elgar, 2009. p. 114-138.

VERCELLI, A. Methodological foundations of macroeconomics: Keynes and Lucas. Cambridge: Cambridge University Press, 1991.

VICTOR, P. A. Managing without growth: slower by design, not disaster. Northampton, MA: Edward Elgar, 2008.

WACKERNAGEL, M.; REES, W. Our ecological footprint: reducing human impact on the earth. Gabriola Island: British Columbia, New Society Publishers, 1996. 